\title{
Sources and origins of aerosols reaching Antarctica as revealed by lead concentration profiles in shallow snow
}

\author{
C. Barbante, ${ }^{1,2}$ C. Turetta, ${ }^{2}$ A. Gambaro, ${ }^{1,2}$ G. Capodaglio, ${ }^{1,2}$ G. Scarponi, ${ }^{1,3}$ \\ ${ }^{1}$ Dipartimento di Scienze Ambientali, Università di Venezia, I-30123 Venice, Italy \\ ${ }^{2}$ Centro di Studio sulla Chimica e le Tecnologie per l'Ambiente - CNR, I-30123 Venice, Italy \\ ${ }^{3}$ Facoltà di Scienze Matematiche, Fisiche e Naturali, Università di Ancona, I-60131 Ancona, Italy
}

\begin{abstract}
Changes in the lead concentration in Antarctic snow over the past 30 years are considered as a response of the environment to a well-documented environmental change (decrease of lead emissions into the atmosphere). New data confirm the recent decreasing trend of lead concentration in snow as revealed by previous studies. Furthermore, comparing changes in the lead concentration in Antarctic snow layers with lead emissions from different anthropic sources, we can hypothesise that under presentday climatic conditions, lead-enriched aerosols reaching the Atlantic and Pacific sectors of East Antarctica originate mainly in South America and Australia, respectively.
\end{abstract}

\section{INTRODUCTION}

Several recent studies have focused on identification of the possible origins and relative contribution of the most important sources of aerosols reaching Antarctica. Both the Last Glacial Maximum (LGM) and present-day climatic conditions have been considered. Some of the studies are based on natural variations in the isotopic composition of lead (Rosman and others, 1994) and neodymium and strontium (Grousset and others, 1992), while others consider the mineralogical nature of clay species (Gaudichet and others, 1992), general atmospheric circulation models (Gaudichet and others, 1992) and the spatial distribution of major ion concentrations (De Angelis and others, 1992; Delmas and Petit, 1994). When different tracers are considered, however, contrasting hypotheses on aerosol origins and pathway are reported.

During the LGM the South American continental shelf, highly exposed during this cold and arid period, is indicated as the main source of rock- and soil-derived aerosols reaching the East Antarctic ice sheet (Grousset and others, 1992; Delmas and Petit, 1994; Rosman and others, 1994), though the Australian continent has also been an important contributor during the same period (De Angelis and others, 1992; Gaudichet and others, 1992).

In present-day climatic conditions mineralogical considerations of clay species and simulations of dust transport using an atmospheric general circulation model (GCM) suggest Australia as the likely origin of aerosols reaching East Antarctica (Gaudichet and others, 1992), while Rosman and others (1994) suggest South America as a likely source for lead, but also consider a possible anthropic contribution from Australia.

The anthropic, long-distance contribution to the lead content of Antarctic snow has increased markedly during the 20th century, particularly since leaded gasolene began to be used as car fuel. Lead concentration in Antarctic snow, which was about $2 \mathrm{pg} \mathrm{g}^{-1}$ at the beginning of the century,

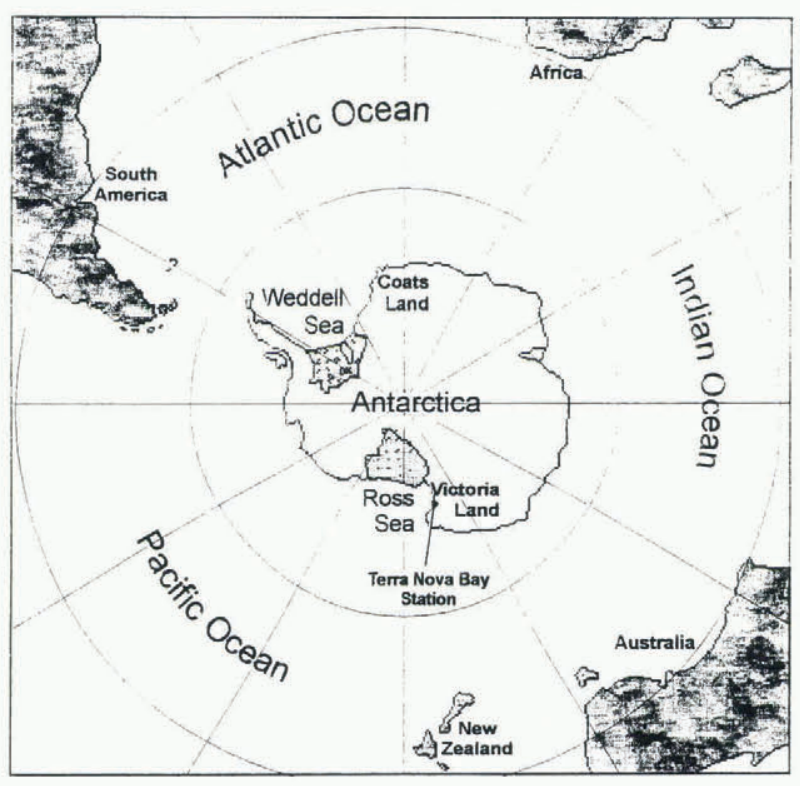

Fig. 1. Map of Antarctica showing the study sites in the Southern Hemisphere.

increased rapidly (particularly from the 1950s) to about $8 \mathrm{pg} \mathrm{g}^{-1}$ in the mid-1970s (Görlach and Boutron, 1992; Wolff and Suttie, 1994). In more recent years, however, the trend has been rapidly inverted, and decreasing values have been observed for snow deposited during the last 20 years both in the Atlantic sector (Coats Land; Wolff and Suttie, 1994) and, more recently, in the Pacific sector (Victoria Land; Scarponi and others, 1997; Barbante and others, 1997b, c) of East Antarctica (see Fig. 1). This general behaviour has been attributed to the increased use of unleaded gasolenes in the countries of the Southern Hemisphere (Wolff and Suttie, 1994; Barbante and others, 1997c).

This paper presents our laboratory's updated data on the lead in Victoria Land snow, and discusses the possible role of lead in tracing the sources and origins of aerosols reaching 
Antarctica today, taking into account the anthropogenic lead emitted by cars and by non-ferrous metal production in the countries of the Southern Hemisphere.

\section{EXPERIMENTAL}

\section{Samples}

Samples of snow refer to three sites in the Victoria Land region, collected during the 1990-91 and 1993-94 Italian scientific expeditions to Antarctica (see Fig. 1; Table 1).

Table 1. Characterisation of sites investigated

\begin{tabular}{|c|c|c|c|c|}
\hline Site & Location & Elevation & $\begin{array}{c}\text { Distance } \\
\text { from the } \\
\text { sea }\end{array}$ & $\begin{array}{c}\text { Mean snow } \\
\text { accumula- } \\
\text { tion rate }\end{array}$ \\
\hline & & $\mathrm{m}$ & $\mathrm{km}$ & $\mathrm{g} \mathrm{cm}^{-2} \mathrm{a}^{-1}$ \\
\hline McCarthy Ridge & $74^{\circ} 32^{\prime} \mathrm{S} 162^{\circ} 56^{\prime} \mathrm{E}$ & 700 & 40 & $27^{a}$ \\
\hline Styx Glacier plateau & $73^{\circ} 52^{\prime} \mathrm{S} 163^{\circ} 42^{\prime} \mathrm{E}$ & 1700 & 50 & $16^{\mathrm{a}}$ \\
\hline Hercules Névé & $73^{\circ} 06^{\prime} \mathrm{S} 165^{\circ} 28^{\prime} \mathrm{E}$ & 2960 & 90 & $17^{\mathrm{b}}$ \\
\hline
\end{tabular}

a From Piccardi and others (1994).

${ }^{\mathrm{b}}$ From Piccardi and others (1995).

Both the trench procedure and coring techniques were used and stringent ultra-clean field procedures were applied (Barbante and others, 1997c). In the case of the snow cores, a special decontamination procedure was carried out which

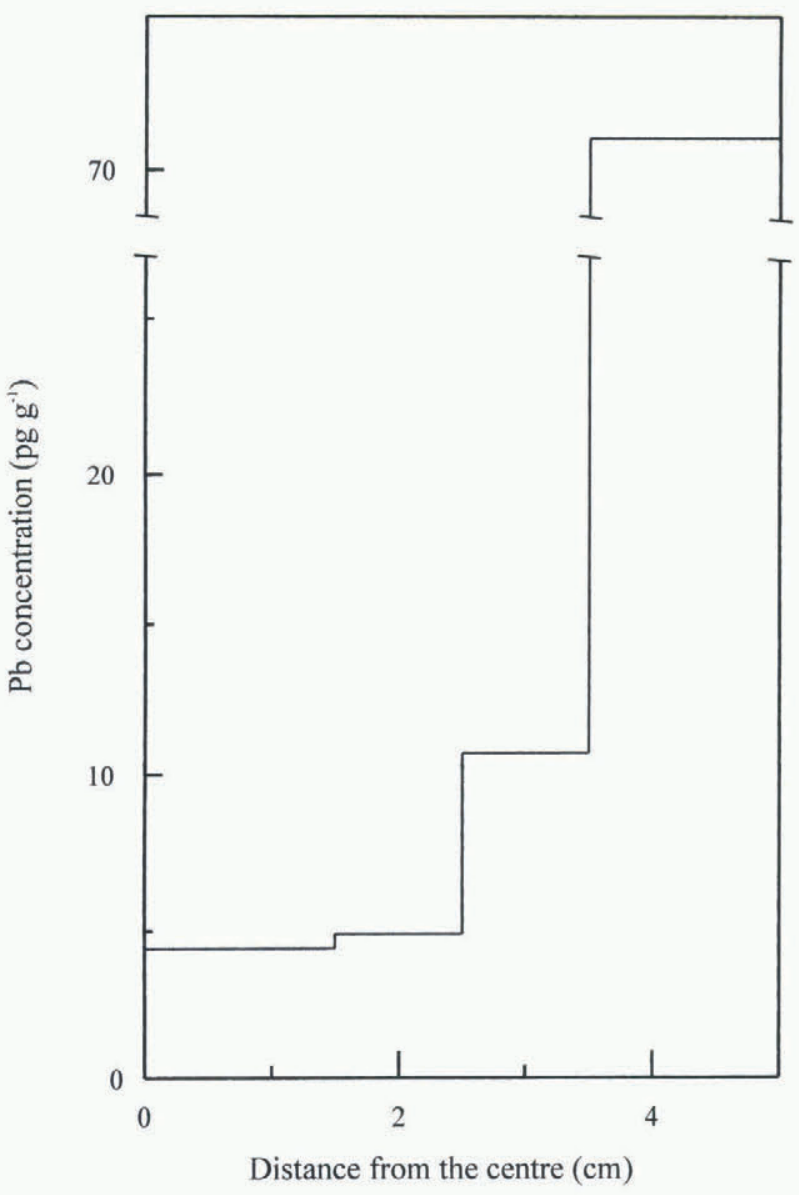

Fig. 2. Lead radial concentration profile for an Antarctic snow core (Hercules Névé, Victoria Land, summer 1993-94, depth $956 \mathrm{~cm})$. enabled three or four concentric layers of snow to be separated. Lead concentration was measured from the outside to the centre in order to obtain radial concentration profiles (Candelone and others, 1994). As an example, the lead radial concentration profile of a snow-core sample collected at $956 \mathrm{~cm}$ depth in Hercules Névé is reported in Figure 2. The radial profile exhibits a clear concentration plateau in the two internal layers, showing that the external contamination of snow cores did not diffuse to the central part of the section. The plateau concentration values therefore represent the real lead concentrations of the core and can be used for data interpretation.

\section{Analytical measurements}

Ultra-pure reagents and water were used throughout the experimental work (Scarponi and others, 1994; Barbante and others, 1997c), and class 100 clean chemistry laboratories were available both at the Italian station at Terra Nova Bay and in Italy. The differential-pulse anodic stripping voltammetry (DPASV) technique was used because of its high sensitivity and its potential for direct analysis of samples, without any pre-concentration (Scarponi and others, 1994).

Selected samples were also analyzed by double-focusing inductively coupled plasma mass spectrometry (ICP-MS; Barbante and others, 1997a) in order to compare the results obtained.

The whole analytical procedure adopted throughout the experimental work is described in detail elsewhere (Scarponi and others, 1994; Barbante and others, 1997a, c).

Particular attention was given to the experimental control of blank contribution for the added acid (Scarponi and others, 1994; Barbante and others, 1997c). Lead concentrations introduced into the samples during acidification were negligibly low, i.e. 1.2 and $20 \mathrm{fg} \mathrm{g}^{-1}$ for the DPASV and double-focusing ICP-MS methodologies, respectively. Thus no blank correction was applied to the instrumental results, considering also the ultra-clean conditions.

Since no reference materials exist for polar snow and ice, in order to check the analytical quality of the data, we measured $\mathrm{Pb}$ in an Antarctic snow-core sample (Hercules Névé, Victoria Land; depth $956 \mathrm{~cm}$ ) by double-focusing ICP-MS. Results of the intercomparison of the two independent techniques are reported in Table 2 and they show good agreement.

Table 2. Comparative determination of $\mathrm{Pb}$ in Antarctic snow by double-focusing ICP-MS and DPASV. Analysis of radial layers of a snow core collected in Hercules. Névé, Victoria Land, East Antartica

\begin{tabular}{lcc}
\hline Layer (from outside) & $\begin{array}{c}\text { Pb concentration } \\
\text { Double focusing ICP-MS } \\
\mathrm{pg} \mathrm{g}^{-1}\end{array}$ & $\begin{array}{c}\text { DPASV } \\
\mathrm{pg} \mathrm{g}^{-1}\end{array}$ \\
\hline 1st & $80^{*}$ & $(77,65)^{*}$ \\
2nd & $11.0^{*}$ & $(8.8,12.6)^{*}$ \\
3rd & 5.0 & 4.9 \\
Central & 5.0 & 4.4 \\
Mean & 5.0 & 4.6 \\
\hline
\end{tabular}

* Values not considered in the mean calculation. 

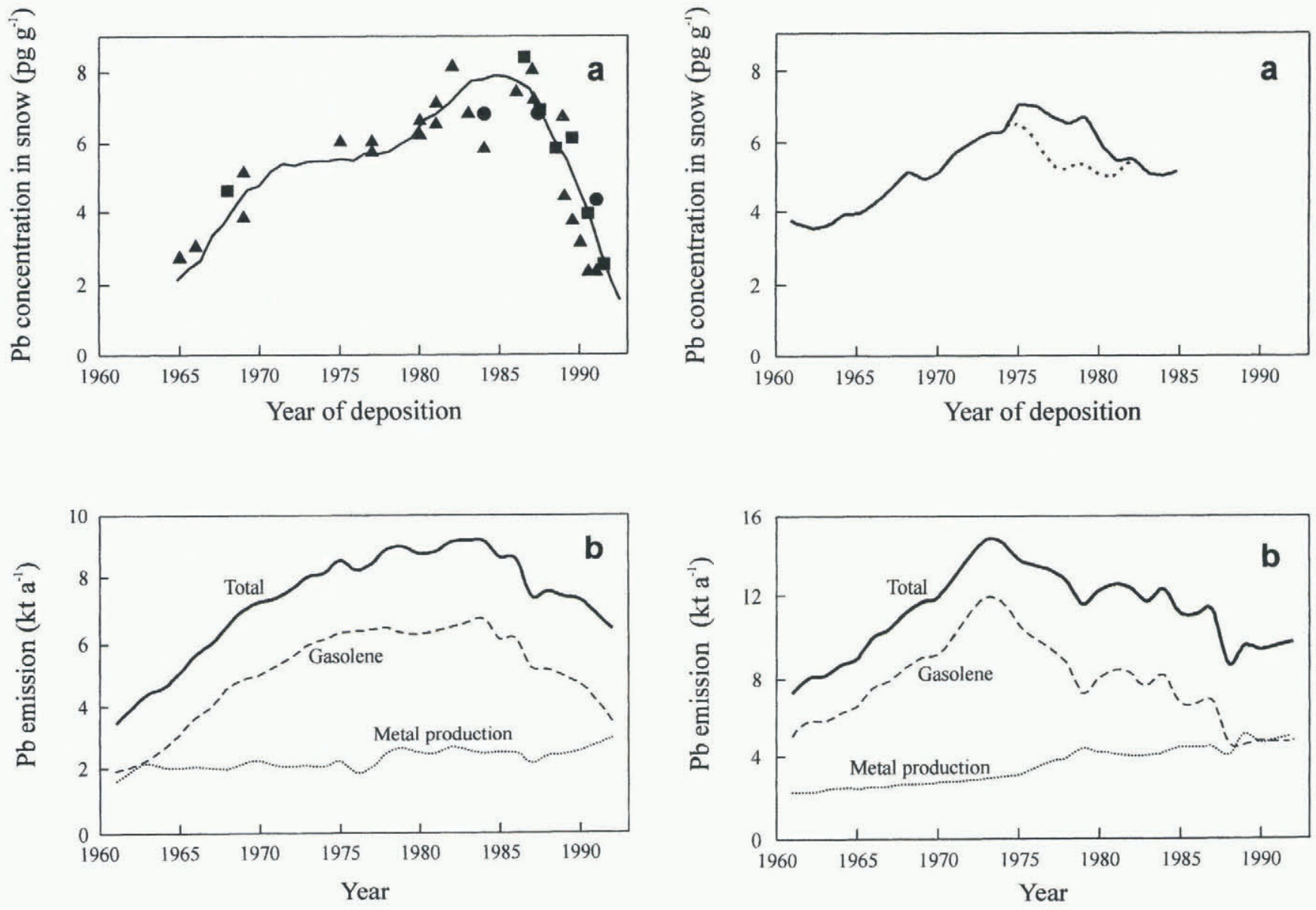

Fig. 3. Temporal trends of (a) lead concentration in Victoria Land snow (•, McCarthy Ridge; $\mathbf{\Delta}$, Styx Glacier; $\mathbf{\square}$, Hercules Névé) and (b) lead emissions in the atmosphere estimated from gasolene consumption and from non-ferrous metal production in Oceania.

Fig. 4. Temporal trends of (a) lead concentration in Coats Land snow (Wolff and Suttie, 1994), smoothed curve, and (b) lead emissions into the atmosphere estimated from gasolene consumption and from non-ferrous metal production in South America (south of the Equator).

\section{RESULTS AND DISCUSSION}

\section{Lead in Antarctic snow}

Figure $3 \mathrm{a}$ shows the trend in $\mathrm{Pb}$ concentration observed in Victoria Land during the last 30 years, according to our updated dataset. The new data recently obtained from Hercules Névé (Scarponi and others, 1997) confirm the trend previously observed at McCarthy Ridge and the Styx Glacier plateau (Scarponi and others, 1994; Barbante and others, 1997c). They reveal that lead content in Antarctic snow increased continuously from the mid-1960s (about $3 \mathrm{pg} \mathrm{g}^{-1}$ ) to the early $1980 \mathrm{~s}$ (maximum about $8 \mathrm{pg} \mathrm{g}^{-1}$ ), after which a marked, rapid decrease took place during the second half of the $1980 \mathrm{~s}$, values falling to $2-4 \mathrm{pg} \mathrm{g}^{-1}$ by 1991 .

Similar behaviour has already been observed in Coats Land (Atlantic sector of East Antarctica) by Wolff and Suttie (1994) with, however, a maximum concentration (about $8 \mathrm{pg} \mathrm{g}^{-1}$ ) during the mid-1970s (see Fig. 4a, and cf. Fig. 3a).

Considering that the residence time of anthropogenic lead-enriched aerosols in the troposphere is fairly short (7-30 days; Ewers and Schlipkoter, 1991), and considering the limited contribution of natural sources to the whole budget of lead in Antarctic snow (about 0.3-0.5 pg g ${ }^{-1}$; Boutron, 1995; Barbante and others, 1997c), the observed trends in the lead concentration profiles were related to the massive emission of

this toxic element into the atmosphere of the Southern Hemisphere as a consequence of non-ferrous metal production and, more importantly in recent years, to the increased emission of lead from modern car engines (Wolff and Suttie, 1994; Scarponi and others, 1997; Barbante and others, 1997c). In fact, car engines emit about $75 \%$ of the lead present in the gasolene as volatile halogeno-lead compounds (Falchi and others, 1992).

\section{Natural and anthropic contributions}

The natural background concentration of lead in Antarctic snow derives mainly from wind-borne rock and soil dust, volcanoes, sea-salt spray, forest fires, continental and marine biogenic particulate and volatile compounds (Görlach and Boutron, 1992; Wolff and Suttie, 1994). A rough calculation of the different natural contributions to the total lead concentration has been obtained, with considerable uncertainty and a large variability, using the global average of $\mathrm{Pb} /$ reference-element mass ratios as known for the various sources (Barbante and others, 1997c). Using this approach, lead contributions from rock and soil dust, volcanic sources and seasalt spray of $0.065,0.15$ and $0.03 \mathrm{pg} \mathrm{g}^{-1}$, respectively, were calculated (Barbante and others, 1997c). Our estimates led to a total natural contribution of about $0.3 \mathrm{pg} \mathrm{g}^{-1}$ of lead.

Considering that over the last 30 years the lead concentration in the snow of Victoria Land ranged from $2.7 \mathrm{pg} \mathrm{g}^{-1}$ 
(in 1965) to $8.1 \mathrm{pg} \mathrm{g}^{-1}$ (in 1982) (Barbante and others, 1997c), the anthropic contribution can be estimated as $2.4-7.8 \mathrm{gg} \mathrm{g}^{-1}$, i.e. it represents $89-96 \%$ of the total amount.

\section{Geographical origins of lead-rich aerosols}

An attempt to identify the geographical origin of aerosols reaching Antarctica was carried out by comparing separately the temporal trends in lead concentration for Victoria Land (Fig. 3a) and Coats Land (Fig. 4a; Wolff and Suttie, 1994) with the trends in lead emissions from gasolene

Table 3. Lead emission factors in the atmosphere for gasolene consumption and non-ferrous metal production

\begin{tabular}{|c|c|c|}
\hline & $\begin{array}{l}\text { Emission } \\
\text { factor }\end{array}$ & Source \\
\hline $\begin{array}{l}\text { Gasolene }\left(\mathrm{g} \mathrm{g}^{-1}\right) \\
\text { Non-ferrous metal production }\end{array}$ & 0.75 & $\begin{array}{l}\text { Falchi and others (1992) } \\
\text { Nriagu and Pacyna } 1988\end{array}$ \\
\hline $\begin{array}{l}\text { Mining }\left(\mathrm{g} \mathrm{t}^{-1}\right) \\
\mathrm{Pb} \text { production }\left(\mathrm{g} \mathrm{t}^{-1}\right) \\
\mathrm{Cu}-\mathrm{Ni} \text { production }\left(\mathrm{g} \mathrm{t}^{-1}\right) \\
\mathrm{Zn}-\mathrm{Cd} \text { production }\left(\mathrm{g} \mathrm{t}^{-1}\right)\end{array}$ & $\begin{array}{c}750 \\
5500 \\
1950 \\
1850\end{array}$ & \\
\hline
\end{tabular}

${ }^{a}$ Average values from ranges reported in the literature.
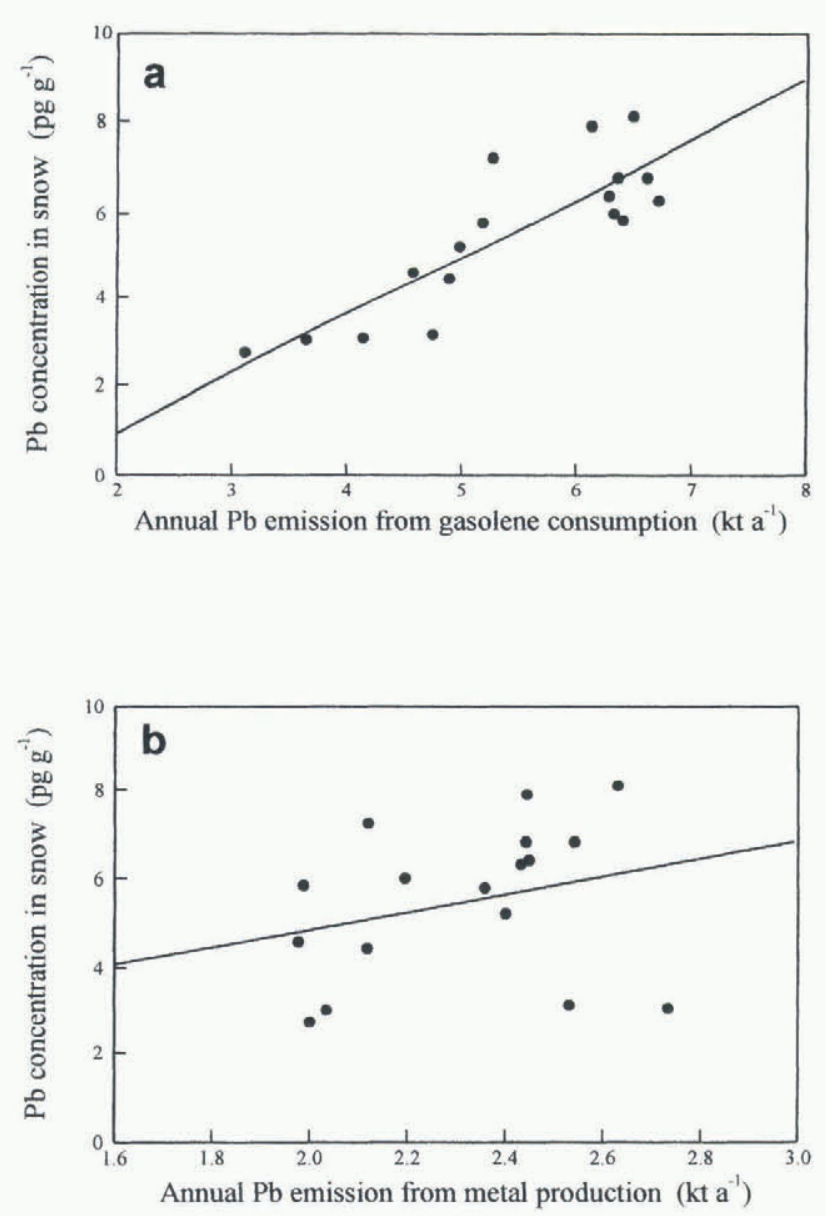

Fig. 5. Relationship between lead concentration in Victoria Land snow and lead emissions from (a) gasolene consumption and $(b)$ non-ferrous metal production, in Oceania. Annual mean $\mathrm{Pb}$ concentrations are used. consumption and from non-ferrous metal production in Oceania and South America, respectively.

To obtain this comparison, inventories of lead emissions into the atmosphere from gasolene combustion and from non-ferrous metal production in the major Southern Hemisphere countries were computed for use together with snow data. These inventories were obtained by multiplying statistical data on lead consumption in gasoline (Octel, 1984-94; personal communication from A.S. Fragomeni, 1995) and on non-ferrous metal production (United Nations, 1965-92) by the respective $\mathrm{Pb}$ emission factors in the atmosphere (Table 3). The results are depicted in Figures $3 \mathrm{~b}$ and $4 \mathrm{~b}$. From these plots it can be seen that gasolene lead emissions into the atmosphere follow approximately the same general pattern observed in the Antarctic snow, while emissions from non-ferrous metal production, although not negligible with respect to the total emissions and more important in South America than in Oceania, are approximately constant, or very slightly increasing, in the period under study (Figs $3 \mathrm{~b}$ and $4 \mathrm{~b}$ ). Moreover, emission inventories from gasolene show that the reduction of emissions in Australia began approximately 10 years later than in South America (especially Brazil) (Octel, 1984-94; Falchi and others, 1992; personal communication A.S. Fragomeni, 1995), which is roughly what was observed in snow data with respect to reduction in $\mathrm{Pb}$ concentration (Fig. $3 \mathrm{a}$ and b).

These findings are supported by the close relationship
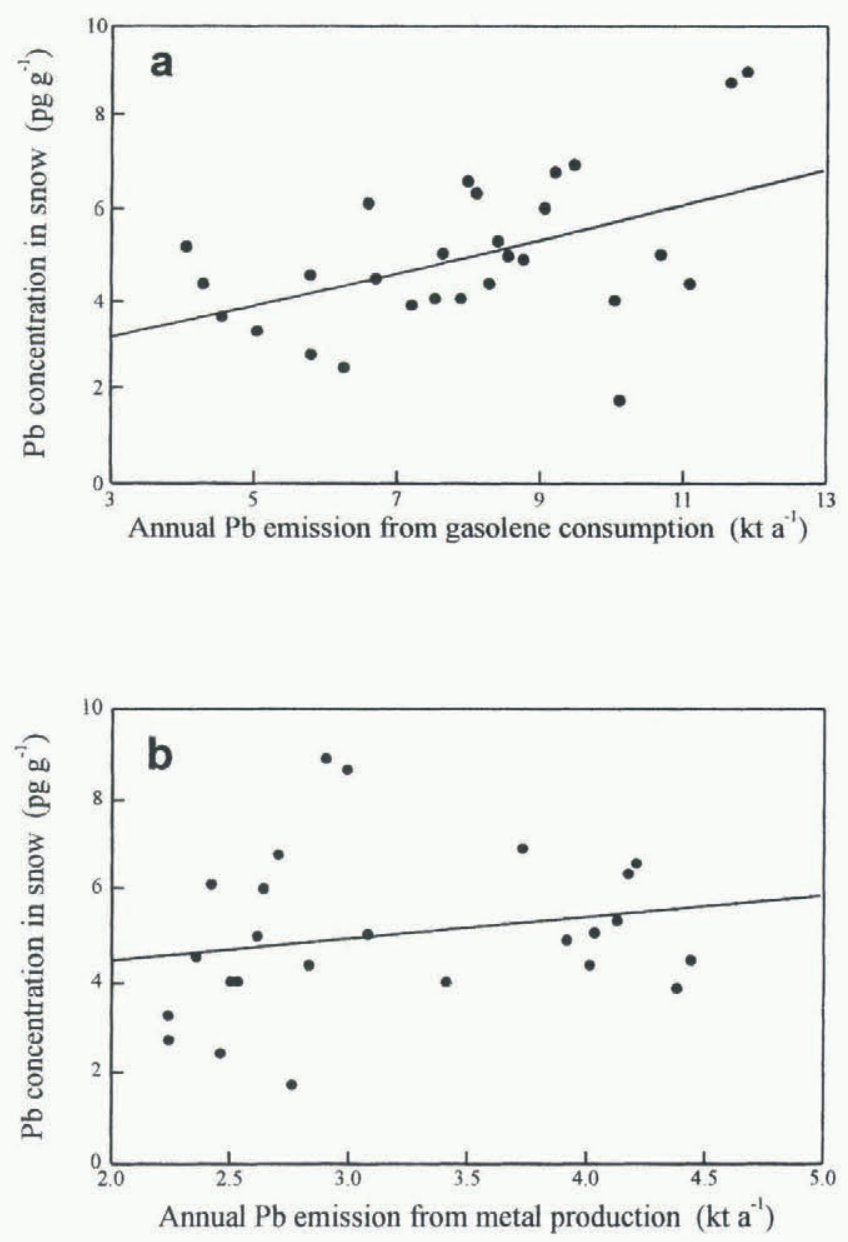

Fig. 6. Relationship between lead concentration in Coats Land snow (Wolff and Suttie, 1994) and lead emissions from (a) gasolene consumption and $(b)$ non-ferrous metal production, in South America (south of the Equator). Annual mean Pb concentrations are used. 
between lead concentration in the snow of Victoria Land, detected by us, and lead emissions from gasolene in Oceania (see Fig. 5a; corr. $0.85, p=0.000013$ ), and by the correlation between the lead concentration in Coats Land snow (Wolff and Suttie, 1994) and the gasolene lead emissions in South America (see Fig. 6a; corr. 0.47, $p=0.011$ ).

Conversely, no apparent relationships are observed when lead concentration in the snow of Victoria Land and Coats Land is plotted against the estimated amounts of lead emitted into the atmosphere during the processes of mining and production of non-ferrous metals in Oceania and South America, respectively. The scatter plots are shown in Figures $5 \mathrm{~b}$ and $6 \mathrm{~b}$, respectively, and correlations in these cases are not significant (corr. 0.27, $p=0.29$; corr. 0.20, $p=0.35$ ).

These results, observed in quite different areas of East Antarctica, suggest that under present-day climatic conditions Australia and South America are the predominant sources for lead-enriched aerosols reaching the Pacific and Atlantic sectors, respectively, of East Antarctica. This finding agrees with model predictions by Gaudichet and others (1992).

\section{CONCLUSIONS}

The updated dataset evaluated here makes it possible to confirm that the introduction of low-lead gasolenes has been reflected in a marked decrease of lead concentration in Antarctic snow. The maximum lead concentration in the snow of the Pacific sector of East Antarctica appears to have occurred about 10 years later than that of the Atlantic sector, possibly because the reduction of lead content in gasolene began at different times in different countries of the Southern Hemisphere. Furthermore, statistical correlations of lead concentration in the snow of Victoria Land (Pacific sector of East Antarctica) and of Coats Land (Atlantic sector) with emissions of lead from gasolene consumption in different areas suggest that, under present climatic conditions, lead-enriched aerosols reaching the Pacific and Atlantic sectors of East Antarctica originate mainly in Australia and South America, respectively.

\section{ACKNOWLEDGEMENTS}

This work was carried out within the framework of projects on "Environmental Contamination" and "Glaciology and Palaeoclimatology" of the Italian Programma Nazionale di Ricerche in Antartide, and was financially supported by Ente Nazionale Energia e Ambiente through cooperation agreements with the Universities of Venice and Milan.

\section{REFERENGES}

Barbante, C. and 9 others. 1997a. Direct determination of heavy metals at pico gram per gram level in Greenland and Antarctic snow by double focusing inductively coupled plasma mass spectrometry. 7. Anal. At. Spectrom., 12, 925-931.

Barbante, C., C. Turetta, T. Bellomi, A. Gambaro, I. Moret and G. Scarponi. 1997b. Possible sources and origins of lead in present-day East Antarctic snow. Geogr. Fi. Din. Quat., 20(2), 199-202.

Barbante, C., C. Turetta, G. Capodaglio and G. Scarponi. 1997c. Recent decrease in the lead content of Antarctic snow. Int. 7. Environ. Anal. Chem., 68(4), 457-477.

Boutron, C. F. 1995. Historical reconstruction of the Earth's past atmospheric environment from Greenland and Antarctic snow and ice cores. Env. Rev., 3, 1-28.

Candelone, J. P., S. M. Hong and C. F. Boutron. 1994. An improved method for decontaminating polar snow or ice cores for heavy metal analysis. Anal. Chim. Acta, 299 (1), 9-16.

De Angelis, M., N. I. Barkov and V. N. Petrov. 1992. Sources of continental dust over Antarctica during the last glacial cycle. F. Atmos. Chem., 14(1-4), 233-244.

Delmas, R. J. and J. R. Petit. 1994. Present Antarctic aerosol composition: a memory of ice age atmospheric dust? Geophys. Res. Lett., 21 (10), 879-882.

Ewers, U. and H.W. Schlipkoter. 1991. Lead. In Merian, E., ed. Metals and their compounds in the environment. Weinheim, Germany, VCH Verlagsgesellschaft mbH, 971-1014.

Falchi, P., D. A. Gidlow and G. R. Searle. 1992. How to obtain rapid improvements in air quality. Milan, Società Italiana Additivi per Carburanti s.r.l.

Gaudichet, A., M. de Angelis, S. Joussaume, J. R. Petit, Ye. S. Korotkevich and V. N. Petrov. 1992. Comments on the origin of dust in East Antarctica for present and ice age conditions. 7. Atmos. Chem., 14(1-4), 129-142.

Görlach, U. and C. F. Boutron. 1992. Variations in heavy metals concentrations in Antarctic snows from 1940 to 1980. 7. Atmos. Chem., 14(1-4), 205-222.

Grousset, F. E. and 6 others. 1992. Antarctic (Dome C) ice-core dust at $18 \mathrm{ky}$ BP; isotopic constraints on origin. Earth Planet. Sci. Lett., 111 (1), 175-182.

Nriagu, J. O. and J. M. Pacyna. 1988. Quantitative assessment of worldwide contamination of air, water and soils by trace metals. Nature, 333(6169), 134-139.

Octel. 1984-94. Worldwide gasoline survey. London, The Associated Octel Company Ltd. (Various issues.)

Piccardi, G., R. Udisti and F. Casella. 1994. Seasonal trends and chemical composition of snow at Terra Nova Bay (Antarctica). Int. f. Environ. Anal. Chem., 55, 219-234.

Piccardi, G., E. Barbolani, S. Becagli, R. Traversi and R. Udisti. 1995. Ruolo della stagionalità e dell'altitudine su fenomeni di frazionamento atmosferico e sulla identificazione di fonti secondarie nelle precipitazioni nevose in Antartide. In Csecon, P., ed. Progetio Nationale di Richerche in Antartide, IV Convegno. Nazionale Contaminazione Ambientale, 6-7 December 1995, Venezia, Italy. Proceedings. Venezia, Università di Venezia, 53-62.

Rosman, K.J. R., W. Chisholm, C. F. Boutron, J.-P. Candelone and C. C. Patterson. 1994. Anthropogenic lead isotopes in Antarctica. Geophys. Res. Lett., 21 (24), 2669-2672.

Scarponi, G., C. Barbante and P. Cescon. 1994. Differential pulse anodic stripping voltametry for ultratrace determination of cadmium and lead in Antarctic snow. Analusis, 22 (7), M47-M50.

Scarponi, G., C. Barbante, C. Turetta, A. Gambaro and P. Cescon. 1997. Chemical contamination of Antarctic snow: the case of lead. Microchem. J., 55, 24-32.

United Nations. 1965-92. United Nations Statistical Yearbook. New York, United Nations. (Various issues.)

Wolff, E.W. and E. D. Suttie. 1994. Antarctic snow record of Southern Hemisphere lead pollution. Geophys. Res. Lett., 21(9), 781-784. 